\title{
NITRIFICATION STUDIES WITH SOIL TYPES IN NORTHERN PUERTO RICO
}

By Juan Amedee Bonnet, Chief of Soits Division, Agricultural Experiment Station, University of Puerto Rico, Río Piedras, P. R.

\section{Scientific Points Relative.to Soll Nitrification}

The suggestion of Pasteur in 1862 that nitrification is due to bacterial action led Winogradsky in 1890 to isolate the organisms concerned in nitrification processes. Since then, nitrification studies have been a subject of investigation in various soils located in countries of different climatic conditions. Among the various aspects studied is worth while mentioning: Nitrification as influenced by soil moisture, temperature, seasonal variations, plant growth, carbonnitrogen ratio, buffering agents, application of fertilizers and amendments; occurrence, isolation, limiting and optimum $\mathrm{pH}$ of soil nitrifying bacteria; nitrification and solubilization of certain soil inorganic elements; methods of studying soil nitrification and nitrifying capacity of a soil as an index of fertility.

It is a well known fact that the soil nitrifying organisms are of an autotrophic nature characterized by the property of obtaining carbon from the carbon dioxide of the atmosphere and their energy by the oxidation of simple inorganic compounds in the form of ammonium salts, and that the process is carried on in two stages: first by a group of bacteria oxidizing ammonia to nitrites (nitrosomonas, nitrosococcus), and then by another group of bacteria oxidizing nitrites to nitrates (nitrobacter). But Gopala Rao and Dhar (13) claim that nitrification in the soil is at least partly photochemical, taking place without the agency of bacteria under the action of sunlight at the surface of various soil photocatalysts like alumina and titania. In further experiments Gopala Rao (12) says: "The slow oxidation of ammonia in aqueous solution to nitrite has been shown to take place in transparent silica vessels under the action of light from a quartz mereury vapor lamp, copper are or more slowly in sunlight." He also calls the attention to the fact that nitrification in the atmosphere and seasonal variations of the nitrate-nitrite contents in favor of the summer months can be successfully explained on the basis of the photochemical view. Fraps and Sterges $(10 \mathrm{~b})$ have shown that photonitrification is of little or no practical importance. 
Two laboratory methods have been used for the study of nitrification: solution or sand method and the most used soil or tumbler method. Although various inorganic and organic nitrogenous sources have been used for such studies, ammonium sulphate and dried blood have been preferred. The solution or sand method supplies information as to the absence or presence of nitrifying bacteria, influence of stimulating substances present in the soil, etc. This method is limited to the use of nitrogenous inorganic sources; since organic materials produce soluble organic compounds and ammonia which are toxic to the nitrifying bacteria. The sensitivity is more pronounced to organic substances in solution than in soil.

It is of great importance in nitrificaton studies to control the concentration of the nitrogenous salt, the $\mathrm{pH}$ range, the time and temperature of incubation and the optimum content of soil moisture. The usual concentration recommended for ammonium sulphate is 30 milligrams of nitrogen per 100 grams dry soil in the presence or absence of 210 milligrams of calcium carbonate which is equivalent to an addition of the theoretical amount of base necessary for the complete neutralization of all the nitric and sulphuric acids formed from the complete oxidation of the nitrogen added. For nitrification of organic nitrogenous materials, 0.25 per cent of organic matter with a high nitrogen content (10-12 per cent), such as dried blood, or 0.5-1.0 per cent of organic materials of a low nitrogen content (cottonseed meal, soy-bean meal, alfalfa meal) should be employed. The usual incubation time and temperature is 30 days at $25-28^{\circ} \mathrm{C}$. For the solution or sand method a temperature of 28 to $30^{\circ} \mathrm{C}$, is recommended. The optimum amount of water used in the tumbler method is from 50 to 60 per cent saturation.

Conditions which tend to promote nitrate formation in the soil are: temperature of $27.5^{\circ} \mathrm{C}$, an abundant supply of air (oxygen), proper moisture supply, a favorable reaction ( $\mathrm{pH}$ greater than 4.6), presence of carbonates or other buffering agents and absence of large quantities of soluble organic matter and alkali salts in the soil. The nature of the crop and the season also influences the nitrate content of the soil.

Although a definite correlation between the nitrifying power of a soil and its crop productivity has been observed by various investigators, some others reported that there may or may not be a correlation, and that continuous cropping, especially without fertilization, reduces the nitrifying capacity of the soil. The subject is fully discussed by Waksman $(32,33)$. Such a correlation may be limited 
by some factor other than the nitrogen supply, such as moisture, temperature, aeration.

Fraps and Sterges (10a) summarize studies on low nitrification capacity of soils as follows: "Soils which do not nitrify ammonium sulphate may be caused to nitrify it by addition of cultures of actively nitrifying soil, of calcium carbonate, or of both nitrifying culture and calcium carbonate. Nitrifying organisms may remain in a dry soil for many years. Nitrites may be produced from ammonium sulphate when calcium carbonate is added, though few nitrates may be produced at the same time."

From the physiological point of view nitrates is no longer considered to be the only form in which nitrogen is absorbed by certain plants. Tiedjens and Robins (29) found that ammonium hydroxide was a much better source of nitrogen than either sulphate of ammonia or calcium nitrate for the tomato and soybean and that ammonia was no more toxic to plants than were nitrates. They further comment: "Pirschle grew wheat, oats, corn, tobacco, cucurbits, peas, beans, soybeans and rape with ammonium sulphate, ammonium chloride, potassium nitrate, and calcium nitrate. $\mathrm{He}$ found that in a neutral culture some plants produced as good growth with ammonia as with nitrate salts or even better, but that an acid and even slightly alkaline reaction, nitrates were superior in most cases. Shive and Stahl state that seedlings absorb more ammonia than nitrate nitrogen but that mature plants require more nitrate nitrogen." In a more recent publication, Tiedjens (30) discusses experimental evidence on factors affecting assimilation (synthesis to amino acids and other organic nitrogenous materials) of nitrogen.

\section{Nitrification Studies With Triopical Solls}

Antipov-Karataev (2) in nitrification studies with soil from the Nikita orchard, Crimea, found: "Intensity of nitrification in orchard soils is similar to that of fallow in the chernozem district. Tobacco and virgin soils give the same amount of nitrates as chernozem soils under corn or sorghum after a fallow. In the shaly soil, low in lime, the process of nitrification was slow. During the period of intensive growth of tobacco no accumulation of nitrates was noted."

Preseott (26) and Roche (28) studied nitrification of Egyptian soils. Prescott says: "Nitrification is well ahead of the needs of the cotton crop, and probably entirely accounts for the fact that nitrogenous fertilizers produce no effect on this crop. There is no accumulation of nitrates in the soil when wheat and maize are grown." 
The work of Prescott also covers observations of seasonal variations of nitrates and pot experiments showing the effect of the growth of maize and wheat on the accumulation of nitrates. The work of Roche includes some observations of rate of nitrification in soils under irrigation.

Peck $(23,24)$ carried some nitrification experiments with soils of Hawaii, using the tumbler method. His results showed that blackstrap molasses from sugar eane removes temporarily part of the available nitrates. Nitrificaton of ammonium sulphate was checked and nitrification of nitrogenous organic fertilizers was retarded by adding molasses. Kelley (20) and Burgess (8) also studied nitrification in soils of Hawaii. Kelley found that nitrification was as active in the manganese and titanium soils as in other soils, but magnesium carbonate was especially toxic. Burgess reports the following data:

\begin{tabular}{|c|c|c|}
\hline \multirow{2}{*}{ Productivity of Soil } & \multicolumn{2}{|c|}{$\begin{array}{l}\text { Nitrifying power } \\
\text { (Mgm. nitrogen per } \\
100 \text { gms. dry soil) }\end{array}$} \\
\hline & Dried blond & Alfalfa mea \\
\hline Best................. & 20.8 & 15.2 \\
\hline Very good......... & $15.2-20.0$ & $9.6-12.8$ \\
\hline Poorer.... & $4.0-13.6$ & $7.2-9.0$ \\
\hline Poorest. & 4.0 & 4.5 \\
\hline
\end{tabular}

In 1927, Bal (4) found in a black soil in India, planted to cotton, that concentrations of over 100 milligrams of ammoniacal nitrogen from ammonium hydroxide are definitely injurious to the process of soil nitrification. Plymen and Bal (25) studied nitrification rates of different nitrogenous organic manures in some typical soils of Berar, India. Hutchinson (17) summarizes investigations on nitrifieation in India soils. Joshi (19) reports on rate of nitrification of different green manures and influence of crop residues on nitrification in India soils. Walton (35) studied the influence of alkali salts on nitrification in some India soils and also (34) the rate of nitrification of calcium cyanamide as compared with ammonium sulphate and mustard cake. Batham (5) compares nitrification rate of certain amino acids and ammonium sulphate in India soils.

Itano and Arakawa (18) report studies in the rice fields of Japan on relation of nitrification to crop yield of rice, seasonal variations and soil specific buffer capacity. 
Wilcox (37) presents a soil nitrification map of the Bandjaratma concession of Java as prepared by Arrhenius who recommends, as sound soil management for a sugar-cane plantation, a map, to show the distribution of the soil's nitrifying power. Arrhenius correlated soil nitrifying power with sugar-cane yields and showed that soil reaction does not parallel nitrate production.

Gerretsen (11) in work with Java soils found that the concentration of ammonium salts through soil adsorption may be so high that nitrification becomes impossible. He claims that the intensity of nitrification in different soils does not necessarily have any direct effect on crop production, and its importance as an index of fertility has often been overrated, although the two frequently run parallel.

Pañganiban (22) reports nitrification studies, with ammonium. sulphate and dried blood, in Philippine soils planted to yautias, corn, banana and cogon. Aquino and Javier (3) report nitrification studies in eighteen different soil types of the Philippine Islands, and Alicante (1) found: "Treatment of citrus soils constitute conclusive evidence that nitrification is an index of crop production. In general, soils devoted to sugar cane converted their original nitrogen into available form more slowly than did those devoted to rice, abacá, tobacco, citrus, etc. Soils containing a high percentage of clay nitrified either the original or the added nitrogen very poorly." He gives data on the average nitrifying power of some of the Philippine soils as compared to those of Hawaii and the United States.

Watt (36) studied nitrification in Transvaal soils. Martin and Massey (21) studied the effect of seasonal variation on the nitrification rate of Sudan soils. Hall (14) studied nitrification rate of some South African soils supplemented with additions of limestone, dried blood, dried cowpea hay, bone meal, ammonium sulphate, whale guano, calcium cyanamide, crayferine and sewage soil. $\mathrm{He}$ also studied seasonal variations of nitrates in virgin, cropped and cultivated lands and nitrate variation with soil depth. In further studies, Hall (15) studied nitrification in some acid soils of South Africa treated with superphosphate, and ammonium sulphate in the presence or absence of lime. He also reports nitrification data in tobaceo soils.

Chardón (9) studied nitrification rate of dried blood in the presence or absence of calcium carbonate in an acid clay around the College of Agriculture at Mayagụez, Puerto Rico. Ramírez (27) 
studied the rate of nitrification of filter press cake residue from a sugar-cane factory added to the red acid clay close to the Insular Experiment Station at Río Piedras, Puerto Rico. He found that nitrate nitrogen from the application to a soil of 15, 25 and 50 tons of filter press cake per acre begins to increase on the third month, goes to a maximum on the fifth month, then the tendency towards the sixth or seventh month is to decrease.

\section{EXPERIMENTAL}

Part 1 contains some of the unpublished research work done by the author in the New Jersey Agricultural Experiment Station, under the direction of the soil microbiologist, Dr. Selman A. Waksman, as contained in a thesis presented in partial fulfillment of the requirement for the degree of Master of Science. The main part of said thesis entitled "Nitrogen transformations in the decomposition of sugar-cane trash, with special bearing upon Puerto Rico soil problems" has been published (6) elsewhere. It also contains some essential data from that thesis reported in a published paper (7) entitled "Preliminary microbiological studies in certain soils of the San Juan area, Puerto Rico".

Part II contains the complete laboratory data of the work done from 1930-1934 in fulfillment of the requirements of a research project of the Insular Experiment Station entitled: "Nitrification studies for a typical soil type in each classified soil series in Puerto Rico." The limitations of our means allowed only to undertake studies with soils from the northern coast of Puerto Rico.

SOILS

The preliminary soil survey maps and reports which are a part of the Soil Survey of Puerto Rico as undertaken since 1928 by the United States Bureau of Chemistry and Soils in cooperation with the Insular Exper'neit Station were used as a basis for soil location, classification and description. The soil types were taken from a list, tentatively called "North Coast Area of Puerto Rico", which was correlated and approved by the Soil Survey Division of the United States Bureau of Chemistry and Soils on March 16, 1934.

Soil Types: The following soil types are included in these studies:

1. Catalina clay. This soil is a deeply weathered soil of the mountain and hill lands. It is derived from andesitic tuffs. The surface ranges from rolling to steep; however, most of the hills are 
rounded with gently sloping ravines. It varies in color from light red to reddish-brown. This soil is well drained but is affected by sheet erosion. It has a friable clay surface whose depth varies with surface relief from about four to eight inches. The subsoil is a reddish-brown or light-red, slightly heavy, but friable clay. At a depth of about 24 inches the soil becomes a deep red clay which continues to great depths. This soil is usually acid. It is used for a variety of crops as cane, citrus, pineapples, coffee and minor crops; and produces profitable yields. This is one of the best coffee soils.

2. Catalina clay level phase. This is the Catalina clay with a nearly level to slightly undulating relief. It is more deeply weathered than the main type as it has not been affected by sheet erosion. Its surface soil is deeper. Farmers prefer it to the main type for most all erops. It is used mostly for cane, citrus and pineapples; all do very well on it.

3. Coto clay light textured phase. This type occurs on nearly level surface relief. It is characterized by a dark grayish-brown, permeable, friable clay about a foot thick underlain by a reddishbrown, slightly compact, permeable clay subsoil and a yellowishbrown, non-plastic clay lower subsoil which usually rests on hard limestone at about 6 feet, but may vary from 26 inches to 12 feet. It is just slightly acid. The most profitable crop adapted to this soil is sugar cane. Other crops producing a good profit are Spanish pepper, tomatoes, corn, ñames, cotton, beans and bananas.

4. Espinosa clay. This type is the acid counterpart of the Coto clay, but has a less yellowish subsoil more mottled in the lower subsoil. In many places the subsoil is quite red. It occurs on gently undulating surfaces in large and small valleys and generally in very well drained positions. It is characterized by a 10-inch surface. horizon of light brown to reddish yellow somewhat stiff and finely cloddy clay upper subsoil, and 15 to 30 inches or more of reddishyellow friable clay which is sometimes mottled red in the deeper horizons. Limestone, the original parent material, occurs at greatly varying depths. It is used almost entirely for sugar-cane production.

5. Lares clay loam. This soil belongs to a group of deeply weathered soils with medium friable subsoils that oceur on terraces or on terrace-like positions, with level to slightly undulating relief. It is affected by gully erosion. It is characterized by a heavy clay' loam surface with a brown to reddish-brown color that crushes fairly easily into granules and some rounded quartz grains. At a depth 
of about 6 inches the soil changes to red or brownish red, heavy, medium plastic clay that eracks some on drying; in the lower part of this layer usually at a depth of only about 14 inches is mottled red and yellowish-medium friable clay. At about 40 inches is a friable red, yellow and brown clay that continues to great depth. In places it looks very much like disintegrated tuff. A characteristic feature of this soil is the noticeable amount of water rounded rocks on this soil and throughout the profile. Many of the rocks are flat and pitted. The rocks near the surface are coated with a layer about $1 / 16$ of an inch thick, eonsisting of a dark mineral, like that composing the perdigon, although very few perdigons are noticed except where this soil grades into Sabana Seca. In the lower depths there will often be gravel layers resembling water deposited gravel. These rounded gravel are of shale, andesite and tuffs. This soil is acid in all layers. It has been influenced by materials from other soil series (Río Piedras and Cialitos). It is used mostly for sugar cane and citrus.

6. Múcara silty clay loam. This undulating to rolling hill soil is easily recognized by its brown surface and light-brown subsoil over a brown igneous rock. It is a medium weathered soil characterized by a dark brownish gray or grayish-brown, gritty silty clay loam surface that is stained lightly in the lower part with gray. This layer is underlain at a depth of about 9 inches by a yellowish, slightly plastic clay or clay loam that has grayish or rust colored mottles. In places small angular fragments of partly weathered rock material occur in this layer and in places the clay is moderately tough and compact. The lower subsoil is a yellowish, light textured, transitional layer consisting of gritty clay loam mixed with partly decomposed rocks. The depth to rock, depending upon the slope, varies from 14 inches to 3 feet. It is affected by sheet erosion. Sugar cane, beans, pigeon peas, corn, yautía, etc., are among the crops planted. Soil depth limits crop yields.

7. Múcara silt loam. This soil differs from the silty clay loam type in having a lighter texture surface and slightly less heavy subsoil.

8. Sabana Seca clay. This is a fertile soil but not very productive because of its heavy stiff subsoil that resists ready penetration of air, plant roots and water. It occurs on nearly level to undulating surface relief, is very acid, and is probably derived from marine deposits. It is characterized by a dark brown, medium compact clay 
surface. At a depth of about 5 to 7 inches there is a thin sub-surface layer about 3 inches thick of light yellow, heavy, medium compact clay; this abruptly changes at about 10 inches to an extremely heavy, stiff, plastic, mottled red, rich brown, gray and yellow clay. This layer continues to a depth of about 30 inches where it becomes gradually lighter in texture and slightly less compact; however, at depths below six feet the soil is still heavy mottled and compact. Cane and pasture are the two best crops grown.

9. Toa silt loam. This is an alluvial, well drained, loose and porous soil developed from material washed from the shale and limestone hills. It is the best sugar-cane soil in the North Coast of Puerto Rico. It is characterized by a grayish-brown color, nearly uniform in both color and texture to a depth of several feet and has very little mottling in the subsoil.

Location of soil samples: The samples used in part I were taken to a depth of six inches with a, shovel, from a single representative spot not under cultivation.

\begin{tabular}{|c|c|}
\hline Soil Types Used in Part I & Location \\
\hline Catalina clay level phase................ & $\begin{array}{l}\text { Km. } 2.25 \text { sideroad from Trujillo Alto mainroad to Leper } \\
\text { Colony. }\end{array}$ \\
\hline Lares clay loam $\ldots \ldots \ldots \ldots \ldots \ldots \ldots \ldots$ & Km. 2.2 Sanatorium road, Rio Piedras. \\
\hline Múcara silty clay loam...$\ldots \ldots \ldots \ldots \ldots$ & Km. 2.8 Carolina-Juneos road. \\
\hline Toa silt loam. & Km. 10.3 San Juan-Bayamón road. \\
\hline
\end{tabular}

The next chart indicates the location of soil samples used in part II. Samples numbered 1-15 inclusive were taken also to a depth of six inches with a shovel in representative spots not under cultivation. Samples 16 and 17 were taken all over the field to a depth of twelve inches with a soil auger; since these samples were also used for other chemical work. 


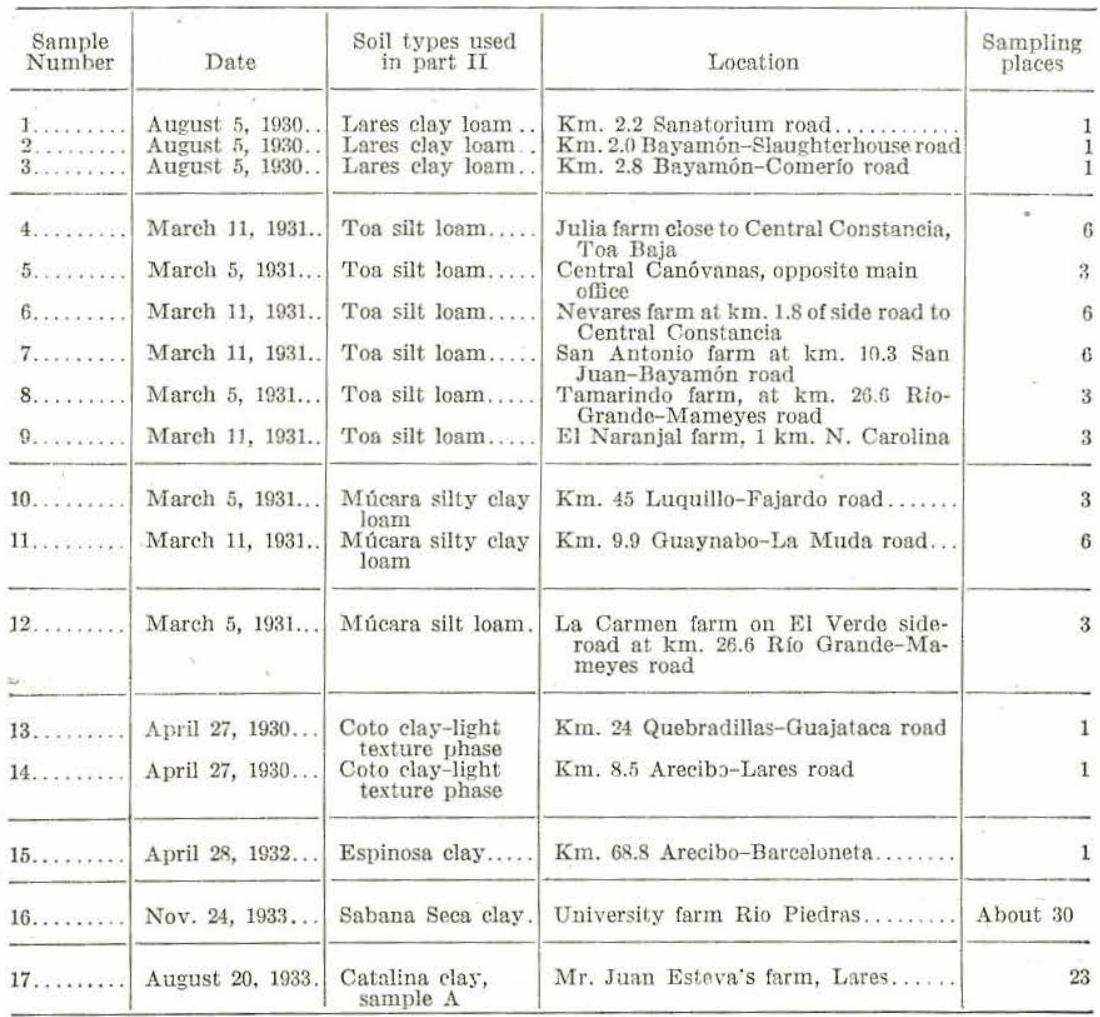

Soil preparation: All samples in part I were sifted in the airdried state through a $2 \mathrm{~mm}$. sieve. All samples in part II were sifted in the fresh state.

Soil analysis and treatments: Moisture and soil total water holding capacity was then determined.

Soils were treated in duplicate according to the Waksman's (31) tumbler method, i.e.

“1. Nitrification of soil's own nitrogen. A definite amount of soil (100 gm.) kept in the laboratory for a definite length of time (30 days) at a definite temperature $\left(25-28^{\circ}\right.$ C. $)$, under optimum moisture conditions, will give us information on the forms of nitrogen present in the particular soil and the speed with which they are transformed into nitrates and thus made available for plant growth.

"2. Nitrification of ammonium sulphate in the soil. By using a definite amount of nitrogen $30 \mathrm{mgm}$. in $100 \mathrm{gm}$. of soil, in the form of ammonium sulphate, and standard period of incubation, we get, from the amount of nitrate formed, an index on the buffering capacity of the soil in relation to nitrification. The final reaction should always be recorded. 
"'3. Nitrification of ammonium sulphate in the presence of a theoretical amount of $\mathrm{CaCO}_{3}, 210 \mathrm{mgm}$. for $30 \mathrm{mgm}$. $\mathrm{N}$ as $\left(\mathrm{NH}_{4}\right)_{2} \mathrm{SO}_{4}$ necessary to nentralize all the acid formed from the complete oxidation of the ammonium sulphate into nitric and sulfuric acid. This gives an index of the nitrifying capacity of the soil under optimum reaction conditions and forms an excellent basis for comparing nitrification with other biological activities.",'

Nitrification of soil's own nitrogen in the presence of the theoretical amount of $\mathrm{CaCO}_{3}$ (210 mgm. for $100 \mathrm{gms}$. dry soil), as used in the ammonium sulfate treatment, was also studied.

In all, but one of the experiments, 60 percent of the soil total water holding capacity was taken for optimum moisture condition. The moisture lost by evaporation during the incubation period of 30 days was replaced at intervals.

Nitrates and ammonia were determined after 15 and 30 days, respectively. In most of the samples those determinations were also made at the start. The usual $\mathrm{pH}$ determinations were made after the 30 -day period. Some $\mathrm{pH}$ determinations were also run at the start.

The phenoldisulphonic colorimetric method was used for nitrates.

In part II, ammonia was determined by direct distillation with magnesia. In part I, ammonia was determined by the Harper's (16) modification which consists in extracting the ammonium ion in the soil with normal potassium chloride and then distilling with magnesia. The determinations for $\mathrm{pH}$ were made with the potentiometer using quinhydrone and a saturated calomel-potassium chloride electrode.

\section{RESEARCH WORK DONE IN NEW JERSEY AGRICULTURAL EXPERIMENT STATION}

The soil type, Sassafras sandy loam, sampled on June 24th, 1929, from the experimental plots of the New Jersey Agricultural Experiment Station at New Bunswick was used as a basis for com. parison.

\section{Nitrification Studies of Puerto Rico Soils at 25 per cent Moisture Content}

A twenty-five percent moisture content was chosen because it represents optimum moisture conditions for the Sassafras sandy loam. This is a productive soil derived from the unconsolidated sands and clays of the coastal plain. 
TABLE I

NITRIFICATION RATE AT TWENTY-FIVE PER CENT MOISTURE UNTREATED SOIL

\begin{tabular}{l|c|c|c|c|c|c}
\hline \multirow{2}{*}{ Soils } & \multicolumn{2}{|c|}{$\mathrm{pH}$} & \multicolumn{3}{|c}{ Mgm. of Nitrogen per 100 gms. dry soil as: } \\
\cline { 3 - 6 } & & \multicolumn{2}{|c|}{ Nitrate } & \multicolumn{2}{|c}{ Ammonia } \\
\hline Toa silt loam............. & 5.8 & 6.0 & 5.9 & 7.4 & 1.1 & 3.4 \\
\hline Catalina clay level phase. & 6.7 & 6.6 & 5.7 & 5.7 & 1.4 & 6.8 \\
\hline Lares clay loam............. & 4.7 & 4.6 & 2.4 & 2.7 & 0.9 & 4.9 \\
\hline Múcara silty clay loam.... & 6.8 & 6.1 & 4.8 & 9.2 & 1.6 & Trace \\
\hline Sassafras sandy loam....... & 5.7 & 5.9 & 6.3 & 6.5 & Trace & Trace \\
\hline
\end{tabular}

SOIL $+30 \mathrm{mgm}$. OF NITROGEN AS $\left(\mathrm{NH}_{4}\right)_{2} \mathrm{SO}_{4}+\mathrm{CaCO}_{3}(210 \mathrm{mgm}$.)

\begin{tabular}{|c|c|c|c|c|c|c|c|c|c|}
\hline \multirow{3}{*}{ Soils } & \multirow{3}{*}{$\begin{array}{c}\mathrm{pH} \\
30 \mathrm{da} .\end{array}$} & \multicolumn{8}{|c|}{ Mgm. of Nitrogen per $100 \mathrm{gms}$. dry soil as. } \\
\hline & & \multicolumn{4}{|c|}{ Nitrate } & \multicolumn{4}{|c|}{ Ammonia } \\
\hline & & Start & $7 \mathrm{da}$. & 14 da. & 30 da. & Start & 7 da. & $14 \mathrm{da}$. & $30 \mathrm{da}$. \\
\hline Toa silt loam............ & 7.1 & 5.9 & 6.7 & 8.3 & 9.4 & 31.1 & 20.3 & 18.7 & 15.1 \\
\hline$\overline{\text { Catalina clay level phase }}$ & 7.4 & 5.7 & 6.1 & 6.0 & 5.3 & 31.4 & 32.2 & 33.1 & 33.6 \\
\hline$\overline{L a r e s}$ clay loam........... & 5.4 & $\overline{2.4}$ & 2.6 & 2.9 & 2.7 & 30.9 & 31.3 & 31.7 & 30.5 \\
\hline$\overline{\text { Múcara silty clay loam.. }}$ & 7.0 & 4.8 & 7.1 & $\overline{9.9}$ & 11.7 & 31.6 & 25.7 & $\overline{24.6}$ & 20.3 \\
\hline Sassafras sandy loa & 5.4 & 6.3 & $\overline{14.6}$ & 22.2 & 30.0 & 30.5 & 19.8 & 11.0 & 2.4 \\
\hline
\end{tabular}

Under the conditions of that experiment there was no nitrate accumulation from the soil's own nitrogen sources in, and from the ammonium sulfate added to, the soil types from Puerto Rico known as Catalina clay level phase and Lares clay loam, although those soils had sufficient ammonia to start the nitrification processes.

In the other soils, the rate of nitrate accumulation goes hand to hand with ammonia disappearance.

The soil from New Jersey had a higher nitrifying rate; but we must consider that the 25 percent moisture content was probably not the optimum one for the two soils from Puerto Rico.

At the start, the $\mathrm{pH}$ of all the soils was in the acid range. Even with the addition of the calcium carbonate, the Lares clay loam had a $\mathrm{pH}$ of 5.4, after the 30-day period. The New Jersey soil had that same $\mathrm{pH}$, but its nitrification rate was quite active. The $\mathrm{pH}$ for the other soils, at the end of the 30-day period was close to the neutral point, in the alkaline side. 


\section{Influence of Lime and Inoculation upon Nitrification in Two Puerto Rico Soils}

In an attempt to find the limiting factor responsible for checking nitrification in the Catalina clay level phase and Lares clay loam, these soils were treated as before; but this time, 500 milligrams of calcium carbonate were added, and treatments also included inoculation of the soils with one cubic centimeter of a 10 percent water infusion of the Sassafras sandy loam. All the soils were kept at a 25 percent moisture content.

\section{TABLE 2}

EFFECT OF LIME AND INOCULATION UPON NITRIFICATION RATE OF CATALINA CLAY LEVEL PHASE AND LARES CLAY LOAM

\begin{tabular}{|c|c|c|c|c|c|}
\hline \multirow{2}{*}{ Treatment } & \multirow{3}{*}{$\begin{array}{c}\mathrm{pH} \\
30 \mathrm{da} .\end{array}$} & \multicolumn{4}{|c|}{$\begin{array}{l}\text { Mgm. of Nitrogen per } \\
100 \text { grams of dry soil }\end{array}$} \\
\hline & & \multicolumn{2}{|c|}{ As Nitrate } & \multicolumn{2}{|c|}{ As Ammonia } \\
\hline & & Start & 30 da. & Start & 30 da. \\
\hline Catalina clay level phase............... & 6.0 & 5.7 & 6.4 & 1.4 & 7.6 \\
\hline Catalina clay level phase $+\left(\mathrm{NH}_{4}\right)_{2} \mathrm{SO}_{4}(30 \mathrm{mgm} . \mathrm{N}.) \ldots$ & 6.8 & 5.7 & 7.2 & 31.4 & 37.5 \\
\hline Catalina clay level phase $+\left(\mathrm{NH}_{4}\right)_{2} \mathrm{SO}_{4}+\mathrm{CaCO}_{3}(500 \mathrm{mgm}$.) & 7.9 & 5.7 & 5.2 & 31.4 & 34.6 \\
\hline Catalina clay level phase $+\left(\mathrm{NH}_{4}\right)_{2} \mathrm{SO}_{4}$. Inoculated..... & 6.8 & 5.7 & 10.0 & 31.4 & $\quad 36.1$ \\
\hline 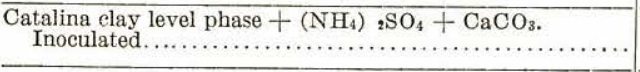 & 7.9 & 5.7 & 4.8 & 31.4 & 31.7 \\
\hline Lares clay loam........... & 5.1 & 2.4 & 2.8 & 9 & 2.2 \\
\hline Lares clay loam $+\left(\mathrm{NH}_{4}\right)_{2} \mathrm{SO}_{4}(30 \mathrm{mgm} . \mathrm{N}.) \ldots \ldots \ldots \ldots$ & 5.1 & 2.4 & 3.0 & 30.9 & 34.6 \\
\hline Lares clay loam $+\left(\mathrm{NH}_{4}\right)_{2} \mathrm{SO}_{4}+\mathrm{CaCO}_{3}(500 \mathrm{mgm}.) \ldots$ & 7.8 & 2.4 & 2.2 & 30.9 & 34.6 \\
\hline Lares clay loam $+\left(\mathrm{NH}_{4}\right)_{2} \mathrm{SO}_{4}$. Inoculated..... & 5.1 & 2.4 & 2.2 & 39.9 & 36.1 \\
\hline Lares clay loam $+\left(\mathrm{NH}_{4}\right)_{2} \mathrm{SO}_{4}+\mathrm{CaCO}_{3}$. Inoculated. & 7.8 & 2.4 & 2.6 & 30.9 & 35.3 \\
\hline
\end{tabular}

The Lares clay loam did not show nitrate accumulation in any of the different treatments. Reaction was not the limiting factor; since the calcium earbonate added, was enough to bring the $\mathrm{pH}$ towards the alkaline side.

The addition of lime did not favor nitrate accumulation in the Catalina clay level phase. Perhaps the alkalinity ( $\mathrm{pH}$ 7.9) did not favor the activity of the nitrifying organisms. That same activity 
was checked at $(\mathrm{pH}$ 7.4) in the previous experiment. Where ammonium sulfate was added alone there was a slight accumulation of nitrates, more so, in the inoculated soil. The reaction in those cases was ( $\mathrm{pH}$ 6.8). Alkaline reactions or the presence of an excess of calcium ions have limiting effects on the activity of the nitriflying organisms in this soil. The next experiment will help to clear these points and indicate whether the effect of inoculation on nitrate accumulation may be considered as significant.

\section{Nitrification Studies of Puerto Rico Soils at Optimum Moisture}

To favor conditions for the activity of the nitrifying organisms the Puerto Rico soils were brought to optimum moisture at 60 percent of the total water holding capacity. This work has been reported elsewhere (8). (In that paper the soil type reported as Río Piedras clay should be Catalina clay level phase; the Bayamón clay loam should be Lares clay loam, and the Múcara clay should be Múcara silty clay loam.) The rate of nitrification of dried blood was also studied. The amount added was 250 milligrams containing 32 milligrams of nitrogen. The calcium carbonate added was 500 milligrams. 
TABLE III

NITRIFICATION RATE OF SOILS AT OPTIMUM MOISTURE

(MGM. N PER 100 GMS. DRY SOIL)

\begin{tabular}{|c|c|c|c|c|c|c|c|c|c|c|}
\hline \multirow{3}{*}{ Treatments } & \multicolumn{5}{|c|}{ Catalina clay level phase } & \multicolumn{5}{|c|}{ Lares clay loam } \\
\hline & \multirow{2}{*}{$\frac{\mathrm{pH}}{30 \mathrm{da} .}$} & \multicolumn{3}{|c|}{ Nitrate } & \multirow{2}{*}{$\frac{\text { Amm. }}{30 \mathrm{da} .}$} & \multirow{2}{*}{$\frac{\mathrm{pH}}{30 \mathrm{da} .}$} & \multicolumn{3}{|c|}{ Nitrate } & \multirow{2}{*}{$\frac{\text { A mm. }}{30 \text { da. }}$} \\
\hline & & Start & 15 da. & 30 da. & & & Start & 15 da. & 30 da. & \\
\hline soii alone $\ldots \ldots \ldots \ldots \ldots \ldots \ldots \ldots$ & 6.5 & 5.7 & 5.5 & 5.5 & 8.6 & 5.0 & 2.4 & 1.6 & 1.8 & 7.6 \\
\hline $\mathrm{Soil}+\mathrm{CaCO}_{3}(500 \mathrm{mgm}.) \ldots \ldots$ & 7.2 & $\cdots \cdots \cdots$ & 5.2 & 5.0 & 5.7 & 7.1 & $\cdots \cdots \cdots$ & 1.9 & 2.2 & 9.4 \\
\hline Soil + dried blood (32 mgm. N).. & 6.6 & $\cdots$ & 3.8 & 5.0 & 27.4 & 5.3 & $\ldots \ldots \ldots$ & 3.0 & 3.4 & 24.9 \\
\hline $\mathrm{Soil}+\left(\mathrm{NH}_{4}\right)_{2} \mathrm{SO}_{4}(30 \mathrm{mgm} . \mathrm{N}) .$. & 6.4 & 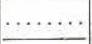 & 5.2 & 5.7 & 35.3 & 4.6 & 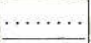 & 1.8 & 1.7 & 33.8 \\
\hline $\mathrm{Soil}+\left(\mathrm{NH}_{4}\right)_{2} \mathrm{SO}_{4}+\mathrm{CaCO}_{3} \ldots .$. & 6.4 & & 4.8 & 10.6 & 13.3 & 7.0 & $\cdots$ & 1.8 & 1.5 & 34.6 \\
\hline
\end{tabular}

TABLE III

NITRIFICATION RATE OF SOILS AT OPTIMUM MOISTURE (MGM. N PER 100 GMS. DRY SOIL)

\begin{tabular}{|c|c|c|c|c|c|c|c|c|c|c|}
\hline \multirow{3}{*}{ Treatments } & \multicolumn{5}{|c|}{ Múcara silty clay loam } & \multicolumn{5}{|c|}{ Toa silt loam } \\
\hline & \multirow{2}{*}{$\frac{\mathrm{pH}}{30 \mathrm{da} .}$} & \multicolumn{3}{|c|}{ Nitrate } & \multirow{2}{*}{$\frac{\text { Amm. }}{30 \mathrm{da} .}$} & \multirow{2}{*}{$\frac{\mathrm{pH}}{30^{\circ} \mathrm{da} .}$} & \multicolumn{3}{|c|}{ Nitrate } & \multirow{2}{*}{$\frac{\text { Amm. }}{30 \mathrm{da} .}$} \\
\hline & & Start & 15 da. & 30 da. & & & Start & 15 da. & 30 da. & \\
\hline Soil alone.. & 6.3 & 4.8 & 8.0 & 12.3 & 2.2 & 6.6 & 5.9 & 6.1 & 7.3 & 6.5 \\
\hline Soil $+\mathrm{CaCO}_{3}(500 \mathrm{mgm}.) \ldots \ldots$ & 7.4 & $\cdots \cdots \cdots$ & 8.0 & 13.3 & 2.2 & 7.6 & $\ldots \ldots \cdots$ & 7.0 & 10.7 & 1.5 \\
\hline Soil + dried blood $(32 \mathrm{mgm} . \mathrm{N}) .$. & 6.5 & & 8.0 & 13.3 & 18.0 & 6.9 & $\cdots$ & 7.0 & 8.6 & 18.0 \\
\hline $\mathrm{Soil}+\left(\mathrm{NH}_{4}\right)_{2} \mathrm{SO}_{4}(30 \mathrm{mgm} . \mathrm{N}) .$. & 6.0 & ......... & 6.7 & 12.0 & 25.2 & 6.3 & . & 5.6 & 6.1 & 23.7 \\
\hline Soil $+\left(\mathrm{NH}_{4}\right)_{2} \mathrm{SO}_{4}+\mathrm{CaCO}_{3} \ldots \ldots$ & 7.1 & ......... & 7.3 & 27.9 & 8.6 & 7.1 & & 8.0 & 19.4 & 9.4 \\
\hline
\end{tabular}


The rate of nitrification of the soil's own nitrogen under optimum conditions was almost identical to that under the 25 percent moisture content reported in Table I. All soils were able to ammonify dried blood. The accumulation of nitrates from dried blood was only evident in the Múcara silty clay loam and Toa silt loam.

Let us compare now the nitrification rate of ammonium sulfate in the presence of lime, under these conditions, with that of the Sassafras sandy loam reported in Table I.

\begin{tabular}{|c|c|c|c|c|c|c|c|c|}
\hline \multirow{3}{*}{ Soil Type } & \multirow{3}{*}{$\begin{array}{l}\text { Opti- } \\
\text { mum } \\
\text { mois- } \\
\text { ture } \\
q\end{array}$} & \multirow{2}{*}{\multicolumn{2}{|c|}{$\mathrm{pH}$}} & \multicolumn{5}{|c|}{$\begin{array}{c}\text { Milligrams of Nitrogen per } 100 \\
\text { gms. dry soil as: }\end{array}$} \\
\hline & & & & \multicolumn{3}{|c|}{ Nitrate } & \multicolumn{2}{|c|}{ Ammonia } \\
\hline & & Start & 30 da. & Start & $15 \mathrm{da}$. & $30 \mathrm{da}$. & Start & 30 da. \\
\hline Lares clay loam...... & 32.8 & 4.7 & 7.0 & 2.4 & 1.8 & -1.5 & 30.9 & 34.6 \\
\hline Catalina clay level phase.......... & 40.0 & 6.7 & 6.4 & 5.7 & 4.8 & 10.6 & 31.4 & 13.3 \\
\hline Toa silt loam............. & 40.0 & 5.8 & 7.1 & 5.9 & 8.0 & 19.4 & 31.1 & 9.4 \\
\hline Múcara silty clay loam........... & 36.0 & 6.8 & 7.1 & 4.8 & 7.3 & 27.9 & 31.6 & 8.6 \\
\hline Sassafras sandy loam.. & 25.0 & 5.7 & 5.4 & 6.3 & 22.2 & 30.0 & 30.5 & 2.4 \\
\hline
\end{tabular}

Optimum moisture and $\mathrm{pH}$ conditions did not favor nitrification in the Lares clay loam; but were effective in showing that the Catalina clay level phase contains active nitrifying organisms able to convert ammonium sulfate into nitrates and that the organisms were not affected by excess of calcium ions.

The rate of nitrification after the 15-day period, for the Puerto Rico soils, is identical with 25 percent and optimum moisture contents. Striking difference is observed after the 30-day period. The nitrification rate was favored in all soils; but the Lares clay loam. Taking the rate of nitrification on the New Jersey soil as 100 percent, the nitrifying Puerto Rico soils, at the end of the 30-day period, compare as follows:

\section{Percentage}

Múcara silty clay loam_-_ 99.67

Toa silt loam -_- 64.67

Catalina clay level phase_-_-_-_._- 35

II. RESEARCH WORK DONE IN THE INSULAR STATION OF PUERTO RICO

Nitrification studies were continued in Puerto Rico, with new samples of soils sifted in the fresh state. 


\section{Further Nitrification Studies with Lares clay loam at Optimum Moisture Conditions}

As the previous experiments indicated lack of nitrate accumulation in the Lares clay loam, three fresh soil samples were taken from different places. Sample \#2 was taken from the same place as that one used in New Jersey. Nitrification of ammonium dibasic phosphate was also studied. The optimum moisture for samples \#1 and \#2 were 45 and 36 percent, respectively.

\section{TABLE IV (a)}

NITRIFICATION RATE OF LARES CLAY LOAM

(MGM. N PER 100 GMS. DRY SOIL)

\begin{tabular}{|c|c|c|c|c|c|c|c|c|c|c|c|c|c|}
\hline \multirow{3}{*}{$\begin{array}{l}\text { Tum- } \\
\text { bler } \\
\text { No. }\end{array}$} & \multirow{3}{*}{ Tratments } & \multicolumn{6}{|c|}{ Sample (No. 1) } & \multicolumn{6}{|c|}{ Sample (No. 2) } \\
\hline & & $\mathrm{pH}$ & \multicolumn{3}{|c|}{ Nitrate } & \multicolumn{2}{|c|}{ Ammonia } & $\mathrm{pH}$ & \multicolumn{2}{|c|}{ Nitrate } & \multicolumn{3}{|c|}{ Ammonia } \\
\hline & & 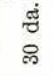 & 营 & 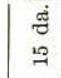 & $\begin{array}{l}\text { ల్ } \\
\text { ల్ }\end{array}$ & $\begin{array}{l}\text { 욤 } \\
\stackrel{2}{\longrightarrow}\end{array}$ & 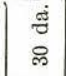 & $\begin{array}{l}\text { हु } \\
\text { हి }\end{array}$ & $\underset{\vec{T}}{\vec{t}}$ & 突 & 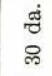 & $\begin{array}{l}\frac{\text { gु }}{2} \\
\text { I2 }\end{array}$ & 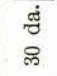 \\
\hline $1 \ldots \ldots$ & Soil.............. & 4.6 & .8 & 1.7 & 2.5 & 5.5 & 5.5 & 4.9 & Tr. & 1.3 & 2.3 & 7.6 & 5.6 \\
\hline 2. & Soil $+\mathrm{CaCO}_{3}(210 \mathrm{mgm})$. & 5.9 & & 3.1 & 5.5 & 7.6 & 11.1 & 5.9 & & 1.6 & 3.1 & 8.8 & 7.6 \\
\hline 3. & $\begin{array}{l}\text { Soil }+\left(\mathrm{NH}_{4}\right) \\
\quad \mathrm{mgm} \\
\mathrm{SOO}_{4}\end{array}$ & 4.7 & & 1.9 & 2.5 & 38.5 & 39.9 & 4.9 & & 1.8 & 1.5 & 36.4 & 35.8 \\
\hline & $\underset{\mathrm{CaCO}_{3}(210 \mathrm{mgm} .)_{2} \ldots}{\text { Soil }}+\underset{\mathrm{NH}_{4} \mathrm{SO}_{4}}{+}+$ & 5.0 & & 4.1 & 8.6 & 37.1 & 33.0 & 6.0 & & 1.7 & 2.9 & 35.7 & 35.8 \\
\hline 5. & 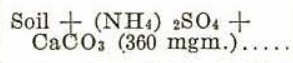 & 5.3 & & 18.3 & 23.9 & 23.4 & 15.1 & 6.3 & & 1.4 & 5.4 & 38.5 & 33.0 \\
\hline $6 \ldots$ & $\begin{array}{l}\text { Soil }+\left(\mathrm{NH}_{4}\right)_{2} \mathrm{HPO}_{4}(30 \\
\text { mgm. } \mathrm{N}) \therefore \ldots \ldots \cdots \cdots \cdots \cdots\end{array}$ & 5.0 & & 2.2 & 3.4 & 35.8 & 37.3 & 5.1 & & 1.8 & 2.5 & 32.3 & 33.0 \\
\hline 7. & $\begin{array}{l}\text { Soil }+\left(\mathrm{NH}_{4}\right) \\
\mathrm{CaCO}_{3} \mathrm{HPO}_{4}+ \\
\mathrm{mgm})\end{array}$ & 4.7 & & 8.3 & 20.3 & 24.8 & 22.0 & 5.8 & & 2.2 & 3.8 & 33.0 & 30.4 \\
\hline
\end{tabular}

Both ammonium salts added to sample \#1 are able to nitrify in the presence of lime. The higher amount of lime (360 mgm.) favored nitrification of ammonium sulfate in both samples, but in sample $\# 2$ the nitrification rate was quite low. Please recall that this fresh sample was taken from the same place as that one used in New Jersey.

It was decided to study nitrification rate of the same ammonium sulfate up to a 60-day incubation period. The moist soils left after the 30-day period in treatments 3,4 and 5 of sample \#2 were modified, as shown below, either by adding more calcium carbonate or 
potassium chloride. The amounts added are in terms of 100 grams dry soil. A and B are duplicates from the 30-day period treated differently. Sample 5A was left as the check.

\section{TABLE IV (b)}

EFFECT OF THE EXTENSION OF THE INCUBATION PERIOD AND PRESENCE OF POTASH AND MORE LIME ON THE NITRIFICATION RATE OF A POOR NITRIFYING, LARES CLAYLOAM

\begin{tabular}{|c|c|c|c|c|c|c|c|}
\hline \multirow{3}{*}{$\begin{array}{l}\text { Tumber } \\
\text { No. }\end{array}$} & \multirow{3}{*}{$\begin{array}{l}\text { Treatment given to sample (No. 2) after } \\
\text { the } 30 \text { day period }\end{array}$} & \multirow{2}{*}{\multicolumn{2}{|c|}{$\mathrm{pH}$}} & \multicolumn{4}{|c|}{$\begin{array}{l}\text { Mgm. N per } 100 \text { gms. } \\
\text { dry soil as: }\end{array}$} \\
\hline & & & & \multicolumn{2}{|c|}{ Nitrate } & \multicolumn{2}{|c|}{ Ammonis } \\
\hline & & 30 da. & $60 \mathrm{da}$. & $30 \mathrm{da}$. & $60 \mathrm{da}$. & $30 \mathrm{da}$. & 60 da. \\
\hline $3 \mathrm{~A} \ldots \ldots \ldots$ & Soil $+\left(\mathrm{NH}_{4}\right)_{2} \mathrm{SO}_{4}+\mathrm{CaCO}_{3}(500 \mathrm{mgm}.) \ldots \ldots$. & 4.9 & 7.1 & 1.5 & 4.4 & 35.8 & 39.5 \\
\hline $3 B \ldots \ldots \ldots$ & Soil $+\left(\mathrm{NH}_{4}\right)_{2} \mathrm{SO}_{4}+\mathrm{CaCO}_{3}(750 \mathrm{mgm}.) \ldots \ldots$ & 4.9 & 7.2 & 1.5 & 3.9 & 35.8 & 43.7 \\
\hline $4 \mathrm{~A} \ldots \ldots \ldots$ & Same as $3 \mathrm{~A} \ldots \ldots \ldots \ldots \ldots \ldots \ldots \ldots \ldots \ldots \ldots \ldots$ & 6.0 & 6.8 & 2.9 & 7.7 & 35.8 & 31.5 \\
\hline $4 \mathrm{~B} \ldots \ldots \ldots$ & Same as $3 \mathrm{~A}+\mathrm{K}_{2} \mathrm{O}$ (30 mgm.) $\ldots \ldots \ldots \ldots \ldots \ldots \ldots \ldots$ & 6.0 & 6.7 & 2.9 & 6.9 & 35.8 & 31.5 \\
\hline $5 \mathrm{~A} \ldots \ldots \ldots$ & CHECK: Soil $+\left(\mathrm{NH}_{4}\right)_{2} \mathrm{SO}_{4}+\mathrm{CaCO}_{3}(360 \mathrm{mgm}.) \ldots$ & 6.3 & 6.1 & 5.4 & 8.7 & 33.0 & 18.7 \\
\hline $5 \mathrm{~B}, \ldots \ldots \ldots$ & $\begin{array}{l}\mathrm{Soil}+\underset{\left(\mathrm{NH}_{4}\right)}{{ }_{2} \mathrm{SO}_{4}+\mathrm{CaCO}_{3}(500 \mathrm{mgm} .)}+\mathrm{K}_{2} \mathrm{O} \\
\quad(100 \mathrm{mgm} .) \\
\cdots \cdots \cdots \cdots \cdots \cdots \cdots \cdots \cdots \cdots \cdots \cdots \cdots \cdots \cdots \cdots \cdots \cdots \cdots \cdots \cdots \cdots\end{array}$ & 6.3 & 6.4 & 5.4 & 13.3 & 33.0 & 14.3 \\
\hline
\end{tabular}

Results indicate that the rate of ammonium sulfate nitrification of Lares clay loam is limited by the length of the incubation period and the absence of lime and potash. 
Nitrification rate of ammonium sulfate and ammonium dibasic phosphate in Lares clay locam

Nitrification rate of ammonium sulfate and ammonium dibasic phosphate in the presence of more lime and potash was studied in sample \#2 of Lares clay loam which showed slight evidence of nitrification after the 30 -day period.

TABLE V

NITRIFICATION RATE OF AMMONIUM SULFATE AND AMMONIUM DIBASIC PHOSPHATE IN A POOR-NITRIFYING LARES CLAY LOAM

\begin{tabular}{|c|c|c|c|c|c|}
\hline \multirow{3}{*}{$\begin{array}{c}\text { Treatment given to Lares clay loam } \\
\text { Sample No. (2) }\end{array}$} & \multirow{3}{*}{$\frac{\mathrm{pH}}{30 \mathrm{da} .}$} & \multicolumn{4}{|c|}{$\begin{array}{l}\text { Mgm. } \mathrm{N} \text { per } 100 \text { gms. dry } \\
\text { dry soil as: }\end{array}$} \\
\hline & & \multicolumn{2}{|c|}{ Nitrate } & \multicolumn{2}{|c|}{ Ammonia } \\
\hline & & $15 \mathrm{da}$. & 30 da. & $15 \mathrm{da}$. & $30 \mathrm{da}$. \\
\hline Soil $+\left(\mathrm{NH}_{4}\right){ }_{2} \mathrm{SO}_{4}(30 \mathrm{mgm} . \mathrm{N})+\mathrm{CaCO}_{3}(500 \mathrm{mgm}.) \ldots$ & 6.7 & .5 & 2.2 & 48.6 & 41.3 \\
\hline$\overline{\text { Soil }+\left(\mathrm{NH}_{4}\right)_{2} \mathrm{SO}_{4}+\mathrm{CaCO}_{3}+\mathrm{K}_{2} \mathrm{SO}_{4}\left(100 \mathrm{mgm} . \mathrm{K}_{2} \mathrm{O}\right) \ldots}$ & 6.4 & .6 & 1.7 & 44.9 & 44.1 \\
\hline$\overline{\text { Soil }+\left(\mathrm{NH}_{4}\right)_{2} \mathrm{HPO}_{4}(30 \mathrm{mgm} . \mathrm{N})+\mathrm{CaCO}_{3}(500 \mathrm{mgm} .) \ldots}$ & 6.3 & .9 & 7.4 & 40.2 & 29.4 \\
\hline Soil $+\left(\mathrm{NH}_{4}\right)_{2} \mathrm{HPO}_{4}+\mathrm{CaCO}_{3}+\mathrm{K}_{2} \mathrm{SO}_{4}\left(100 \mathrm{mgm} . \mathrm{K}_{2} \mathrm{O}\right)$. & 6.3 & .7 & 7.1 & 39.8 & 37.0 \\
\hline
\end{tabular}

Dibasic ammonium phosphate nitrifies in the presence of 500 milligrams of calcium carbonate without the influence of potash. The ammonium sulfate showed a very slight tendency to nitrify in the presence of sufficient lime and potash. It seems therefore, that the presence of the phosphate ion in the presence of sufficient lime favors the nitrification process in this soil. 


\section{Nitrification studies in another sample of Lares clay loam}

Nitrification studies of ammonium sulfate and ammonium dibasic phosphate were made in a sample of Lares clay loam from a different location. The treatments given are shown in Table VI.

TABLE VI.

NITRIFICATION RATE OF ANOTHER SAMPLE OF LARES CLAY LOAM

\begin{tabular}{|c|c|c|c|c|c|c|}
\hline \multirow{3}{*}{$\begin{array}{c}\text { Treatments given to Sample (No. } 3 \text { ). } \\
\text { Optimum moisture- } 30 \%\end{array}$} & \multirow{3}{*}{$\frac{\mathrm{pH}}{30 \mathrm{da} .}$} & \multicolumn{5}{|c|}{ Mgm. N. per 100 gms. dry scil as } \\
\hline & & \multicolumn{3}{|c|}{ Nitrate } & \multicolumn{2}{|c|}{ Ammonia } \\
\hline & & Start & 15 da. & $30 \mathrm{da}$. & 15 da. & 30 da. \\
\hline 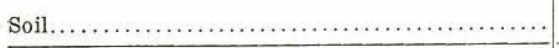 & 5.6 & $\operatorname{Tr} \ldots$ & 1.7 & 2.4 & 9.9 & 8.9 \\
\hline 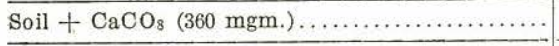 & 7.1 & . & 7.7 & 6.7 & 7.1 & 8.1 \\
\hline $\mathrm{Soil}+\left(\mathrm{NH}_{4}\right)_{2} \mathrm{SO}_{4}(30 \mathrm{mgm} . \mathrm{N}) \ldots \ldots \ldots \ldots \ldots \ldots$ & 5.5 & $\ldots \ldots \ldots$ & 1.3 & 2.0 & 40.1 & 39.5 \\
\hline $\mathrm{Soil}+\left(\mathrm{NH}_{4}\right)_{2} \mathrm{SO}_{4}+\mathrm{CaCO}_{3}(360 \mathrm{mgm}.) \ldots \ldots \ldots$ & 5.3 & • & 25.0 & 19.3 & 11.5 & 7.2 \\
\hline $\mathrm{Soil}+\left(\mathrm{NH}_{4}\right)_{2} \mathrm{SO}_{4}+\mathrm{CaCO}_{3}(500 \mathrm{mgm}.) \ldots \ldots$. & 6.4 & & 13.8 & 36.4 & 99 & 3.6 \\
\hline $\begin{aligned}\text { Soil } \underset{(360 \mathrm{mgm}}{+})_{2} \mathrm{NH}_{4} \mathrm{HPO}_{4}(30 \mathrm{mgm} . \mathrm{N})+\mathrm{CaCO}_{3} \\
\quad\end{aligned}$ & 6.0 & . & 13.8 & 36.4 & 7.8 & 2.9 \\
\hline Preceding treatment $+\mathrm{KCl}\left(100 \mathrm{mgm} . \mathrm{K}_{2} \mathrm{O}\right) \ldots$ & 5.7 & & 8.5 & 19.3 & 16.5 & 7.2 \\
\hline
\end{tabular}

The amount of lime was a dominant factor in the nitrification of both ammonium salts. The ammonium sulfate maximum nitrification was obtained with 500 milligrams of calcium carbonate. That same maximum nitrification was obtained with the ammonium dibasic phosphate; but in the presence of less lime $(360 \mathrm{mgm}$. $\mathrm{CaCO}_{3}$ ). The potash had no effect.

NITRIFICATION STUDIES IN SIX SAMPLES OF TOA SILT LOAM

\begin{tabular}{|c|c|c|}
\hline $\begin{array}{l}\text { Sample } \\
\text { Number }\end{array}$ & Location & $\begin{array}{l}\text { Optimum } \\
\text { moisture } \\
\text { (60\% of } \\
\text { total } \\
\text { water } \\
\text { holding } \\
\text { capacity }\end{array}$ \\
\hline $4 \ldots \ldots \ldots$ & 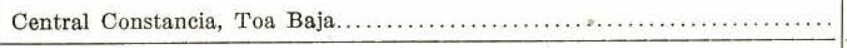 & 47.70 \\
\hline $5 \ldots \ldots \cdots$ & 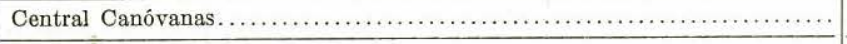 & 35.40 \\
\hline $6 \ldots \ldots \ldots$ & 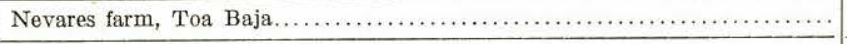 & 40.20 \\
\hline $7 \ldots \ldots \ldots$ & 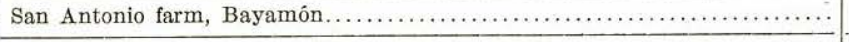 & 43.80 \\
\hline $8 \ldots \ldots \ldots$ & 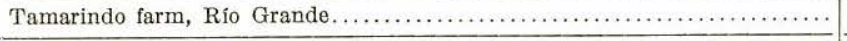 & 39.90 \\
\hline $9 \ldots \ldots \ldots$ & El Naranjal farm, Carolina.... & 36.00 \\
\hline
\end{tabular}


TABLE VII

NITRIFICATION RATE OF TOA SILT LOAM

(MGM .N PER 100 GMS. DRY SOIL)

\begin{tabular}{|c|c|c|c|c|c|c|c|c|c|c|c|c|c|c|c|c|c|c|c|c|c|}
\hline \multirow{3}{*}{ Treatments } & \multicolumn{7}{|c|}{ Soil Number (4) } & \multicolumn{7}{|c|}{ Soil Number (5) } & \multicolumn{7}{|c|}{ Soil Number (6) } \\
\hline & \multicolumn{2}{|c|}{$\mathrm{pH}$} & \multicolumn{3}{|c|}{ Nitrate } & \multicolumn{2}{|c|}{ Ammonia } & \multicolumn{2}{|c|}{$\mathrm{pH}$} & \multicolumn{3}{|c|}{ Nitrate } & \multicolumn{2}{|c|}{ Ammonia } & \multicolumn{2}{|c|}{$\mathrm{pH}$} & \multicolumn{3}{|c|}{ Nitrate } & \multicolumn{2}{|c|}{ Ammonia } \\
\hline & Start & $30 \mathrm{da}$. & Start & $15 \mathrm{da}$ & $30 \mathrm{da}$. & $15 \mathrm{da}$. & 30 da. & Start & $30 \mathrm{da}$ & Start & $1 E \mathrm{da}$ & 30 da. & 15 da. & 30 da. & Start & $30 \mathrm{da}$. & Start & 15 da. & $30 \mathrm{da}$. & 15 da. & $30 \mathrm{da}$. \\
\hline Soil....................... & 6.3 & 6.2 & N.D* & 2.5 & 4.5 & 5.2 & 6.6 & 5.8 & 5.2 & .4 & 2.7 & 3.1 & 7.4 & 6.6 & 5.7 & 5.7 & N.D* & 4.0 & 4.9 & 7.4 & 7.4 \\
\hline Soil $+\mathrm{CaCO}_{3}(210 \mathrm{mgm}.) \ldots$ & $\cdots \cdots$ & 6.7 & $\cdots \cdots$ & 4.3 & 4.7 & 9.5 & 8.1 & $\ldots \ldots$ & 5.9 & $\cdots \cdots$ & 2.9 & 3.8 & 6.6 & 5.9 & $\cdots \cdots$ & 6.1 & $\ldots \cdots$ & 4.8 & 5.9 & 7.4 & 5.9 \\
\hline Soil $+\left(\mathrm{NH}_{4}\right)_{2} \mathrm{SO}_{4}(30 \mathrm{mgm} . \mathrm{N})$ & $\ldots \ldots$ & 5.5 & $\ldots \ldots$ & 23.5 & 26.7 & 11.1 & 5.9 & $\cdots \cdots$ & 4.8 & $\ldots \ldots$ & 5.3 & 10.8 & 23.5 & 18.3 & $\because$ & 6.5 & $\cdots \cdots$ & 15.4 & 15.4 & 15.4 & 11.1 \\
\hline Soil $+\left(\mathrm{NH}_{4}\right)_{2} \mathrm{SO}_{4}+\mathrm{CaCO}_{3} \ldots$ & $\ldots \ldots$ & 5.9 & $\cdots \cdots$ & 28.8 & 26.7 & 6.6 & 7.4 & $\ldots \ldots$. & 5.1 & 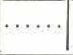 & 18.2 & 21.6 & 14.0 & 8.1 & & 5.7 & & 34.8 & $\overline{23.5}$ & $\overline{4.2}$ & 4.5 \\
\hline
\end{tabular}

TABLE VII

NITRIFICATION RATE OF TOA SILT LOAM

(MGM .N PER 100 GMS. DRY SOIL)

\begin{tabular}{|c|c|c|c|c|c|c|c|c|c|c|c|c|c|c|c|c|c|c|c|c|c|}
\hline \multirow{3}{*}{ Treatments } & \multicolumn{7}{|c|}{ Soil Number (7) } & \multicolumn{7}{|c|}{ Soil Number (8) } & \multicolumn{7}{|c|}{ Soil Number (9) } \\
\hline & \multicolumn{2}{|c|}{$\mathrm{pH}$} & \multicolumn{3}{|c|}{ Nitrate } & \multicolumn{2}{|c|}{ Ammonia } & \multicolumn{2}{|c|}{$\mathrm{pH}$} & \multicolumn{3}{|c|}{ Nizrate } & \multicolumn{2}{|c|}{ Ammonia } & \multicolumn{2}{|c|}{$\mathrm{pH}$} & \multicolumn{3}{|c|}{ Nitrate } & \multicolumn{2}{|c|}{ Ammonia } \\
\hline & Start & $30 \mathrm{da}$. & Start & 15 da. & $30 \mathrm{da}$. & $15 \mathrm{da}$. & $30 \mathrm{da}$. & Start & 30 da. & Start & 15 da. & 30 da. & $15 \mathrm{da}$ & $30 \mathrm{da}$ & Start & 30 da. & Stait & $15 \mathrm{da}$ & $30 \mathrm{da}$ & $15 \mathrm{da}$. & 30 da. \\
\hline Soil $\ldots \ldots \ldots \ldots \ldots \ldots \ldots \ldots \ldots \ldots \ldots \ldots \ldots$ & 6.1 & 5.7 & 4.8 & 4.5 & 4.9 & 5.9 & 7.4 & 5.6 & 5.3 & .4 & 4.8 & 7.4 & 5.2 & 5.9 & 7.1 & 6.2 & .4 & 3.6 & 2.9 & 2.9 & 5.2 \\
\hline Soil $+\mathrm{CaCO}_{3}(210 \mathrm{mgm}.) \ldots$. & $\ldots \ldots$ & 6.4 & $\ldots \ldots$ & 4.1 & 4.9 & 8.0 & 7.4 & $\cdots \cdots$ & 6.3 & $\cdots$ & 6.2 & 6.3 & 5.9 & 6.6 & $\ldots \ldots$ & 6.6 & $\ldots \ldots$ & 3.9 & 3.8 & 7.4 & 5.2 \\
\hline Soil $+\left(\mathrm{NH}_{4}\right)_{2} \mathrm{SO}_{4}(30 \mathrm{mgm} . \mathrm{N})$ & $\cdots \cdots$ & 5.4 & $\cdots \cdots$ & 6.6 & 10.3 & 24.4 & 19.9 & - & 5.2 & 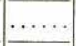 & 6.8 & 8.3 & 39.1 & 25.8 & $\ldots \ldots$ & 5.8 & $\ldots \ldots$ & 4.8 & 8.7 & 25.8 & 21.4 \\
\hline$\overline{\mathrm{Soil}}+\left(\mathrm{NH}_{4}\right)_{2} \mathrm{SO}_{4}+\mathrm{CaCO}_{3 . .}$ & $\overline{\cdots \cdots}$ & 5.5 & $\ldots$ & $\overline{12.5}$ & 21.1 & 22.1 & 6.7 & 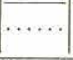 & 5.4 & $\ldots \ldots$ & 8.7 & $\overline{14.8}$ & $\overline{23.5}$ & 11.8 & . & 6.0 & .... & 14.8 & $\overline{23.5}$ & $\overline{10.4}$ & 6.6 \\
\hline
\end{tabular}

*N, D.-Not determined, 
NITRIFICATION STUDIES IN THREE SAMPLES OF MÚCARA SOILS

\begin{tabular}{|c|c|c|c|}
\hline $\begin{array}{l}\text { Sample } \\
\text { Number }\end{array}$ & Soil Type & Location & $\begin{array}{c}\text { Optimum } \\
\text { moisture } \\
\text { (60\% of } \\
\text { total } \\
\text { water } \\
\text { holding } \\
\text { capacity }\end{array}$ \\
\hline $10 \ldots \ldots \ldots$ & 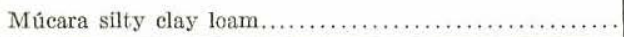 & Luquillo......... & 37.2 \\
\hline $11 \ldots \ldots \ldots \ldots$ & Múcara silty clay loam.............................. & Guaynabo...... & 36.3 \\
\hline $12 \ldots$ & Múcara silt loam.... & Río Grande..... & 39.6 \\
\hline
\end{tabular}

TABLE VIII

NITRIFICATION RATE OF MÚCARA SOILS

(MGM. N PER 100 GMS. DRY SOIL)

\begin{tabular}{|c|c|c|c|c|c|c|c|c|c|c|c|c|c|c|c|c|c|c|}
\hline \multirow{3}{*}{ Treatments } & \multicolumn{6}{|c|}{ Soil Number (10) } & \multicolumn{6}{|c|}{ Soil Number (11) } & \multicolumn{6}{|c|}{ Soil Number (12) } \\
\hline & \multirow{2}{*}{$\frac{\mathrm{pH}}{30 \mathrm{da} .}$} & \multicolumn{3}{|c|}{ Nitrate } & \multicolumn{2}{|c|}{ Ammonia } & \multirow{2}{*}{$\frac{\mathrm{pH}}{30 \mathrm{da} .}$} & \multicolumn{3}{|c|}{ Nitrate } & \multicolumn{2}{|c|}{ Ammonia } & \multirow{2}{*}{$\frac{\mathrm{pH}}{30 \mathrm{da}}$} & \multicolumn{3}{|c|}{ Nitrate } & \multicolumn{2}{|c|}{ Ammonia } \\
\hline & & Start & $15 \mathrm{da}$. & $30 \mathrm{da}$. & $15 \mathrm{da}$ & $30 \mathrm{da}$. & & Start & 15 da. & $30 \mathrm{da}$ & $15 \mathrm{da}$. & $30 \mathrm{da}$. & & Start & $15 \mathrm{da}$. & $30 \mathrm{da}$. & 15 da. & 30 da. \\
\hline Soil ....................................... & 6.7 & Tr... & 5.9 & 11.8 & 3.6 & 4.5 & 6.1 & Tr... & .5 & 1.3 & 6.7 & 8.1 & 5.5 & $\operatorname{Tr} \ldots$ & 4.9 & 17.2 & 15.5 & 4.5 \\
\hline 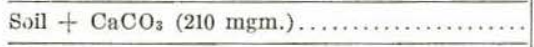 & 7.4 & $\ldots \ldots$ & 6.3 & 13.8 & 4.5 & 2.9 & 6.3 & $\ldots \ldots$ & 1.8 & 6.9 & 6.7 & 2.9 & 5.9 & $\cdots \cdots$ & 8.2 & 18.9 & 8.1 & 2.9 \\
\hline Soil $+\left(\mathrm{NH}_{4}\right)_{2} \mathrm{SO}_{4}(30 \mathrm{mgm} . \mathrm{N}) \ldots \ldots \ldots \ldots \ldots \ldots$ & 6.7 & $\ldots \ldots$ & 11.1 & 24.7 & 5.2 & 3.6 & 5.4 & $\ldots$ & .5 & 1.0 & 35.6 & 35.6 & 5.8 & $\overline{\ldots \ldots}$ & 3.8 & 16.3 & 41.4 & 28.1 \\
\hline$\overline{\mathrm{Soil}}+\left(\mathrm{NH}_{4}\right)_{2} \mathrm{SO}_{4}+\mathrm{CaCO}_{3} \ldots \ldots \ldots \ldots \ldots \ldots \ldots$ & 7.0 & ..... & 11.1 & 25.7 & 4.5 & 2.9 & 5.3 & $\overline{\cdots \cdots}$ & 37 & 18.5 & 31.1 & $\overline{12.6}$ & 5.8 & $\overline{\ldots \ldots}$ & 8.3 & $\overline{27.8}$ & $\overline{29.5}$ & 5.9 \\
\hline
\end{tabular}


The Toa silt loam is a good nitrifying soil for ammonium sulfate in the absence or presence of lime. The addition of lime does not favor the nitrification rate of the soil's own nitrogen.

The presence of lime favored nitrification in all samples of Múcara soils. Samples \#10 and \#12 are good nitrifiers of the soil's own nitrogen and of the ammonium sulfate added.

NITRIFICATION STUDIES IN COTO CLAY-LIGHT TEXTURE PHASE AND ESPINOSA CLAY

\begin{tabular}{|c|c|c|c|}
\hline $\begin{array}{l}\text { Sample } \\
\text { Number }\end{array}$ & Soil Type & Location & $\begin{array}{l}\text { Optimum } \\
\text { moisture } \\
\text { (60\% of } \\
\text { total } \\
\text { water } \\
\text { holding } \\
\text { capacity }\end{array}$ \\
\hline $13 . . .$. & 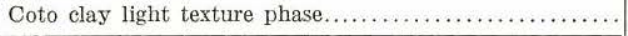 & Quebradillas.... & 42.8 \\
\hline $14 \ldots \ldots \ldots$ & Coto clay light texture phase $\ldots \ldots \ldots \ldots \ldots \ldots \ldots \ldots \ldots \ldots \ldots$ & Arecibo.......... & 35.4 \\
\hline 15. . & Espinosa clay... & Barceloneta..... & 40.1 \\
\hline
\end{tabular}

TABLE IX

NITRIFICATION RATE OF COTO CLAY LIGHT TEXTURE PHASE (MGM. N PER 100 GMS. DRY SOIL)

\begin{tabular}{|c|c|c|c|c|c|c|c|c|c|c|c|c|}
\hline \multirow{3}{*}{ Treatments } & \multicolumn{6}{|c|}{ Sample Number (13) } & \multicolumn{6}{|c|}{ Sample Number (14) } \\
\hline & \multicolumn{2}{|c|}{$\mathrm{pH}$} & \multicolumn{2}{|c|}{ Nitrate } & \multicolumn{2}{|c|}{ Ammonia } & \multicolumn{2}{|c|}{$\mathrm{pH}$} & \multicolumn{2}{|c|}{ Nitrate } & \multicolumn{2}{|c|}{ Ammonia } \\
\hline & Start & 30 da. & $15 \mathrm{da}$. & $30 \mathrm{da}$. & $15 \mathrm{da}$. & 30 da. & Start & $39 \mathrm{da}$ & $15 \mathrm{da}$. & 30 da. & $15 \mathrm{da}$. & 30 da. \\
\hline Soil.. & 6.0 & 5.6 & 4.1 & 5.8 & 12.1 & 12.8 & 6.1 & 5.7 & 2.6 & 3.6 & 12.9 & 12.1 \\
\hline $\mathrm{Soil}+\mathrm{CaCO}_{3}(210 \mathrm{mgm})$. & & 5.7 & 5.2 & 6.6 & 12.9 & 12.8 & & 6.0 & 3.2 & 4.4 & 12.9 & 12.9 \\
\hline $\begin{array}{c}\text { Soil + } \\
\text { mgm. } \\
\left(\mathrm{NH}_{4}\right) \\
\left.\mathrm{N}_{2}\right)_{2} \mathrm{SO}_{4}(30 \\
\ldots \ldots \ldots \ldots\end{array}$ & & 5.4 & 13.0 & 22.2 & 27.7 & 26.3 & & 5.3 & 6.9 & 40.0 & 31.8 & 13.6 \\
\hline $\begin{array}{l}\text { Soil }+\left(\mathrm{NH}_{4}\right)_{2} \mathrm{SO}_{4}+ \\
\mathrm{CaCO} \mathrm{CO}_{3} \ldots \ldots \ldots \ldots \ldots \ldots\end{array}$ & & 5.2 & 16.2 & 35.4 & 21.0 & 12.9 & & 5.2 & 29.6 & 40.0 & 13.5 & 12.2 \\
\hline
\end{tabular}


TABLE X

NITRIFICATION RATE OF ESPINOSA CLAY

(MMG. N PER 100 GMS. DRY SOIL)

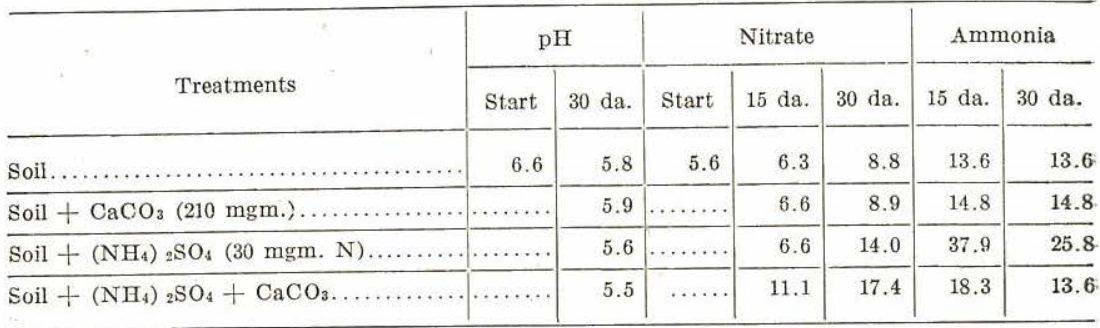

The Coto and Espinosa soils are able to nitrify the ammonium sulfate in the absence of lime.

\section{NITRIFICATION STUDIES IN SABANA SECA CLAY AND CATALINA CLAY}

\begin{tabular}{|c|c|c|c|c|}
\hline $\begin{array}{l}\text { Sample } \\
\text { Number }\end{array}$ & Soil Type & - & Location & $\begin{array}{c}\text { Optimum } \\
\text { moisture } \\
\text { (60\% of } \\
\text { total } \\
\text { water } \\
\text { holding } \\
\text { capacity }\end{array}$ \\
\hline $16 \ldots \ldots \ldots$ & Sabana Seca Clay .................. & $\ldots \ldots \ldots \ldots \cdots$ & Rio Piedras..... & 27.6 \\
\hline $17 \ldots \ldots \ldots$ & $\begin{array}{l}\text { Catalina Clay ........................ } \\
\text { Plot (A) }\end{array}$ & 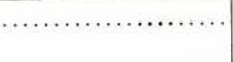 & Lares............ & 39.0 \\
\hline
\end{tabular}

TABLE XI

NITRIFICATION RATE OF SABANA SECA CLAY

\begin{tabular}{|c|c|c|c|c|c|c|}
\hline \multirow{3}{*}{ Treatments } & \multirow{2}{*}{\multicolumn{2}{|c|}{$\mathrm{pH}$}} & \multicolumn{4}{|c|}{ Mgm. N per 100 gms. dry soil as: } \\
\hline & & & \multicolumn{2}{|c|}{ Nitrate } & \multicolumn{2}{|c|}{ Ammonia } \\
\hline & Start & $30 \mathrm{da}$. & 15 da. & 30 da. & 15 da. & 30 da. \\
\hline Soil .................... & 5.4 & 5.3 & .7 & 3.3 & 9.1 & 5.0 \\
\hline $\mathrm{Soil}+\mathrm{CaCO}_{3}(210 \mathrm{mgm}.) \ldots \ldots \ldots \ldots \ldots \ldots \ldots \ldots$ & n....... & 6.5 & 1.2 & 5.4 & 9.8 & 5.0 \\
\hline Soil $+\left(\mathrm{NH}_{4}\right)_{2} \mathrm{SO}_{4}(30 \mathrm{mgm} . \mathrm{N}) .$. & .. & 5.3 & .7 & 3.6 & 40.0 & 38.8 \\
\hline $\mathrm{Soil}+\left(\mathrm{NH}_{4}\right)_{2} \mathrm{SO}_{4}+\mathrm{CaCO}_{3}$. & & 5.8 & .6 & 8.3 & 41.4 & 28.7 \\
\hline
\end{tabular}


TABLE XII

NITRIFICATION RATE OF CATALINA CLAY

(MGM. N PER 100 GMS. DRY SOIL)

\begin{tabular}{|c|c|c|c|c|c|c|}
\hline \multirow[b]{2}{*}{ Treatments } & \multicolumn{2}{|c|}{$\mathrm{pH}$} & \multicolumn{2}{|c|}{ Nitrate } & \multicolumn{2}{|c|}{ Ammonia } \\
\hline & Start & 30 da. & 15 da. & 30 da. & $15 \mathrm{da}$. & 30 da. \\
\hline .................... & 4.6 & 4.8 & .9 & .9 & 9.1 & 10.5 \\
\hline Soil $+\mathrm{CaCO}_{3}(210 \mathrm{mgm}.) \ldots \ldots \ldots \ldots \ldots \ldots \ldots \ldots \ldots$ & $\ldots \ldots \ldots$ & 5.1 & .8 & 1.3 & 9.8 & 11.1 \\
\hline Soil $+\left(\mathrm{NH}_{4}\right)_{2} \mathrm{SO}_{4}(30 \mathrm{mgm} . \mathrm{N}) \ldots \ldots \ldots \ldots \ldots \ldots \ldots \ldots \ldots$ & $\overline{\ldots \ldots \ldots}$ & 4.7 & .7 & .9 & 40.3 & $\overline{40.9}$ \\
\hline $\mathrm{Soil}+\left(\mathrm{NH}_{4}\right)_{2} \mathrm{SO}_{4}+\mathrm{CaCO}_{3}$. & & 5.1 & .7 & 1.1 & 43.5 & 45.5 \\
\hline
\end{tabular}

Lime helps the nitrification process of the Sabana Seca clay.

The treatments given to the Catalina clay were not effective in starting the nitrification process. The amount of lime added (210 mgm. $\mathrm{CaCO}_{3}$ ) was not enough to correct the excess acidity of this soil.

\section{General Discussion}

Let us now compare in table XIII the nitrification rate, at the end of the thirty-day period, of all the soils worked out, under similar conditions, in the preceding experiments.

Table XIII gives valuable information on the relation of soil $\mathrm{pH}$ to nitrate and ammonia accumulation. It also compares the nitrification and ammonification rate of the different soil types and the extent of variation of such processes within various samples of the same soil type. It offers valuable information as to whether ammonium sulfate should be used as source of nitrate for plant assimilation and whether it should prove advisable to lime the soil in order to hasten the nitrifying rate of ammonium sulfate or to use nitrate salts as a source of nitrogen.

Results indicate that ammonium sulfate should not be used as a source of nitrate for plants in the Lares clay loam, Sabana Seca clay and Catalina clay, and in some of the Múcara silty clay loam, unless special attention is given to lime broadeasting. The lime might be partially beneficial in the Lares clay loam and Catalina clay. It should also prove advisable, in those soils and in Sabana Seca clay, to apply part of the nitrogen as nitrate salts, preferably calcium nitrate.

Ammonium sulfate nitrifies quite well in the Toa silt loam, Coto clay light texture phase and Espinosa clay, even in the absence of lime. The application of ammonium sulfate as a source of nitrate 
TABLE XIII

COMPARISON OF NITRIFICATION RATE OF SOME PUERTO RICO SOILS AND A NEW JERSEY SOIL AT OPTIMUM MOISTURE ON THE BASIS OF NITRIFICATION RATE AFTER THIRTY DAY PERIOD

(MGM. N. PER 100 gms. DRY SOIL)

\begin{tabular}{|c|c|c|c|c|c|c|c|c|c|c|c|c|c|}
\hline \multirow[b]{2}{*}{$\begin{array}{l}\text { Sample } \\
\text { No. }\end{array}$} & \multirow{2}{*}{ Soil Type } & \multicolumn{4}{|c|}{ Soil's own nitrogen } & \multicolumn{4}{|c|}{$\begin{array}{l}\text { Ammonium sulfate } \\
(30 \mathrm{mgm} . \mathrm{N})\end{array}$} & \multicolumn{4}{|c|}{$\begin{array}{l}\text { Ammonium sulfate* } \\
(30 \mathrm{mgm} . \mathrm{N}) \text { and } \\
\mathrm{CaCO}_{3}(210 \mathrm{mgm} .)\end{array}$} \\
\hline & & $\mathrm{pH}$ & $\underset{\text { 营 }}{\stackrel{\Xi}{\leftrightarrows}}$ & $\begin{array}{l}\text { 吉 } \\
\text { 号 } \\
\text { 豆 } \\
\text { 足 }\end{array}$ & 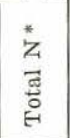 & $\mathrm{pH}$ & 䓌 & $\begin{array}{l}\text { 吕 } \\
\text { 品 } \\
\text { 品 }\end{array}$ & 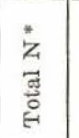 & $\mathrm{pH}$ & 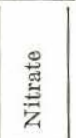 & 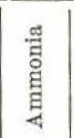 & 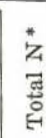 \\
\hline $1 . \ldots \ldots \ldots$ & Lares clay loam. . & 4.6 & 2.5 & 5.5 & 8.0 & 4.7 & 2.5 & 39.9 & 42.4 & 5.0 & 8.6 & 33.0 & 41 \\
\hline $2 \ldots \ldots \ldots$ & Lares clay loam....... & 4.9 & 2.3 & 5.6 & 7.9 & 4.9 & 1.5 & 35.8 & 37.3 & 6.0 & 2.9 & 35.8 & $3 \varepsilon$ \\
\hline Ave........ & 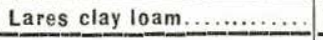 & 4.8 & 24 & 5.6 & 8.0 & 4.8 & 20 & 37.9 & 39.9 & 5.5 & 58 & 344 & 40 \\
\hline $4 \ldots \ldots \ldots$ & Toa silt loam $\ldots \ldots \ldots \ldots \ldots$ & 6.2 & 4.5 & 6.6 & 11.1 & 5.5 & 26.7 & $5: 9$ & 32.6 & 5.9 & 26.7 & 7.4 & 3. \\
\hline $5 \ldots \ldots \ldots$ & Toa silt loam... & 5.2 & 3.1 & 6.6 & 9.7 & 4.8 & 10.8 & 18.3 & 29.1 & 5.1 & 21.6 & 8.1 & 2 \\
\hline $6 \ldots$ & Toa silt loam............... & 5.7 & 4.9 & 7.4 & 12.3 & 6.5 & 15.4 & 11.1 & 26.5 & 5.7 & 23.5 & 4.5 & 2 \\
\hline $7 \ldots \ldots \ldots$ & Toa silt loam ................. & 5.7 & 4.9 & 7.4 & 12.3 & 5.4 & 10.3 & 19.9 & 30.2 & 5.5 & 21.1 & 6.7 & 2 \\
\hline $8 \ldots \ldots \ldots$ & Toa silt loam................ & 5.3 & 7.4 & 5.9 & 13.3 & 5.2 & 8.3 & 25.8 & 34.1 & 5.4 & 14.8 & 11.8 & 2 \\
\hline $9 \ldots \ldots \ldots$ & Toa silt loam.............. & 6.2 & 2.9 & 5.2 & 8.1 & 5.8 & 8.7 & 21.4 & 30.1 & 6.0 & 23.5 & 6.6 & 3 \\
\hline Ave........ & 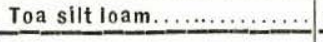 & 5.7 & 46 & 65 & 11.1 & 55 & 134 & 171 & 30.5 & 56 & 21.9 & 7.5 & $2 !$ \\
\hline $10 .$. & Múcara silty elay loam..... & 6.7 & 11.8 & 4.5 & 16.3 & 6.7 & 24.7 & 3.6 & 28.3 & 7.0 & 25.7 & 2.9 & \& \\
\hline $11 \ldots \ldots \ldots$ & Múcara silty clay loam..... & 6.1 & 1.3 & 8.1 & 9.4 & 5.4 & 1.0 & 35.6 & 36.6 & 5.3 & 18.5 & 12.6 & $\vdots$ \\
\hline Ave........ & Múcara silty clay loam........ & 64 & 6.6 & 63 & 12.9 & 61 & 12.9 & 196 & 32.5 & 6.2 & $\underline{2} 2.1$ & 7.8 & $\underline{2}$ \\
\hline $12 .$. & Múcara silt loam ............ & 5.5 & 17.2 & 4.5 & 21.7 & 5.8 & 16.3 & 28.1 & 44,4 & 5.8 & 27.8 & 5.9 & : \\
\hline $13 .$. & Coto clay light texture phase & 5.6 & 5.8 & 12.8 & 18.6 & 5.4 & 22.2 & 26.3 & 48.5 & 5.2 & 36.4 & 12.9 & \\
\hline $14 \ldots$ & Coto clay light texture phase & 5.7 & 3.6 & 12.1 & 15.7 & 5.3 & 40.0 & 13.6 & 53.6 & 5.2 & 40.0 & 12.2 & \\
\hline Ave. & 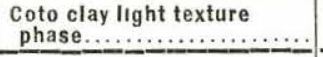 & 5.7 & 4.7 & 125 & 17.2 & 5.4 & 311 & 20.0 & 5:.1 & 5.2 & 38.2 & 12.6 & 5 \\
\hline $15 \ldots \ldots \ldots$ & Espinosa clay............... & 5.8 & 8.8 & 13.6 & 22.4 & 5.6 & 14.0 & 25.8 & 39.8 & 5.5 & 17.4 & 13.6 & \\
\hline $16 \ldots \ldots \cdots$ & Sabana Seca clay...$\ldots \ldots \ldots$ & 5.3 & 3.3 & 5.0 & 8.3 & 5.3 & 3.6 & 38.8 & 42.4 & 5.8 & 8.3 & 28.7 & \\
\hline \multirow[t]{2}{*}{$17 \ldots \ldots \ldots$} & Catalina elay .......... & 4.8 & .9 & 10.5 & 11.4 & 4.7 & .9 & 40.9 & 41.8 & 5.1 & 1.1 & 45.5 & \\
\hline & $\begin{array}{l}\text { Sassafras sandy loam, New } \\
\text { Jersey........................ }\end{array}$ & 5.9 & 6.5 & Trace & 6.5 & & & & & 5.4 & 30.0 & 2.4 & \\
\hline
\end{tabular}

* Total $\mathrm{N}$ is the sum of nitrate and ammonia. 
for plant growth should prove beneficial in those soils without considering the practice of lime broadeasting.

The thirty milligrams of nitrogen added as ammonium sulfate was accounted for, as nitrate and ammonia in all the soils. The slight excess of total nitrogen found in some cases, was due to the formation of ammonia by those active soil organisms able to decompose the soil's own protein material.

Let us now compare the average results given in Table XIII on a percentage basis. The results obtained with the Toa silt loam were taken as a basis for the comparison, since that alluvial soil is the most valuable and productive in the northern coast of Puerto Rico:

TABIE XIV

COMPARISON OF NITRIFICATION RATE ON AVERAGE BASIS

\begin{tabular}{|c|c|c|c|c|c|c|}
\hline \multirow{3}{*}{ Soil Types } & \multicolumn{6}{|c|}{ Thirty Day Nitrifying Period } \\
\hline & \multicolumn{2}{|c|}{ Soil's own nitrogen } & \multicolumn{2}{|c|}{$\begin{array}{l}\text { Ammonium sulfate } \\
\text { (30 mgm. N) }\end{array}$} & \multicolumn{2}{|c|}{$\begin{array}{c}\text { Ammonium sulfate }+ \\
\mathrm{CaCO}_{3} \\
(210 \mathrm{mgm} .)\end{array}$} \\
\hline & $\begin{array}{c}\text { Nitrate } \\
(\mathrm{Mgm} . \mathrm{N})\end{array}$ & Percent & $\begin{array}{c}\text { Nitrate } \\
\text { (Mgm. N) }\end{array}$ & Percent & $\begin{array}{c}\text { Nitrate } \\
(\mathrm{Mgm} . \mathrm{N})\end{array}$ & Percent \\
\hline Toa silt loam............. & 4.6 & 100 & 13.4 & 100 & 21.9 & 100 \\
\hline Lares clay loam........... & 2.4 & 52 & 2.0 & 15 & 5.8 & 26 \\
\hline Múcara silty clay loam.... & 6.6 & 143 & 12.9 & 96 & 22.1 & 101 \\
\hline Múcara silt loam........... & 17.2 & 374 & 16.3 & 122 & 27.8 & 127 \\
\hline Coto clay light texture phase & 4.7 & 102 & 31.1 & 232 & 38.2 & 175 \\
\hline Espinosa clay .............. & 8.8 & 191 & 14.0 & 104 & 17.4 & 79 \\
\hline Sabana Seca clay.......... & 3.3 & 72 & 3.6 & 27 & 8.3 & 38 \\
\hline Catalina clay ............. & .9 & 20 & .9 & 7 & 1.1 & 5 \\
\hline Sassafras sandy loam...... & 6.5 & 141 & & & 30.0 & 137 \\
\hline
\end{tabular}

\section{Summary}

Experimental results have been reported on the nitrification rate of nine soil types from Northern Puerto Rico classified as: Catalina clay, Catalina clay level phase, Coto clay light texture phase, Espinosa clay, Lares clay loam, Múcara silty clay loam, Múcara silt loam, Sabana Seca clay and Toa silt loam. The various soil types are represented by twenty-one different soil samples. Some experimental data is also reported for a soil type from New Jersey classified as Sassafras sandy loam. 
The main object of the work was to establish a correlation on the following bases:

1. Nitrification of soil's own nitrogen.

2. Nitrification of soil's own nitrogen as affected by the addition of lime.

3. Nitrification of ammonium sulfate in the soil.

4. Nitrification of ammonium sulfate as affected by the addition of lime.

Studies were also carried with various samples of the same soil type in order to study the nitrifying range within the soil type.

All soils were similarly treated with respect to incubation period, temperature, and time; optimum moisture conditions; and concentration of lime and ammonium sulfate added to the soil.

The soil types known as Catalina clay level phase and Lares clay loam which showed a slight response to the above general treatments were also studied with respect to the influence of more lime and inoculation upon nitrification. One soil sample of Lares clay loam which also showed a slight response to inoculation and extra lime addition was also studied with respect to the effect of the extension of the incubation period and addition of potash in the presence of various amounts of lime. The nitrification rate of ammonium sulfate and ammonium dibasic phosphate was also compared in that soil.

Table XIII summarizes the experimental results comparing the nitrification and ammonification rate of the different soil types similarly treated and the variations of such a rate within various samples of the same soil type. Those results should prove of value in the practical application of ammonium sulfate as a fertilizer and indicate if it is advisable to lime the soil in order to hasten the nitrification rate of ammonium sulfate or to apply part of the nitrogen in the form of nitrate salts.

Table XIV contains data on the comparison of the nitrification rate of the various soils treated on a percentage basis. The most productive and valuable alluvial soil type of the north coast of Puerto Rico, Toa silt loam, was taken as the unit basis.

\section{Conclusions}

1. Ammonium sulfate should not be used as a source of nitrate for plants in the Lares clay loam, Sabana Seca clay and Catalina clay, and in some fields of Múcara silty clay loam, unless special attention is given to lime broadcasting. It should be more advisable to apply ammonium dibasic phosphate instead of ammonium sulfate. to Lares clay loam, after special attention is given to lime broad. 
casting. Although the lime might be beneficial in the Lares clay loam and Catalina clay, it should also prove advisable, in those soils, and in Sabana Seca clay, to apply part of the nitrogen as nitrate salts, preferably calcium nitrate.

2. Ammonium sulfate nitrifies quite well in the Toa silt loam, Coto clay light texture phase, and Espinosa clay, even in the absence of lime. The application of ammonium sulfate as a source of nitrate for plant growth should prove beneficial in those soils without considering of upmost importance the practice of lime broadeasting.

\section{Literature Citeid}

1. Alicante, MI. Nitrifying power of some Philippine soils. Philippine Journ. Sci. 32(1): 1-27, 1927.

2. Antipov-Karataev, I. N. (Nitrification in the soils of the Nikita orchard in the year 1925). Journ. Gvt. Bot. Gard. Nikita Yalta. Crimea 9(2): 54 p., 1926.

3. Aquino, D. I. \& Javier, V. I. Nitrification studies of certain Philippine soils. Philippine Agr. 21 (5) : 309-317, 1932.

4. Bal, D. V. Effect of varying concentrations of ammonia on the nitrifying power of the soil. Agr. Journ. India 22(4) :298300, 1927.

5. Batham, H. N. Nitrification in soils. Soils Se. $20(5): 337-351$, 1925.

6. Bonnet, J. A. Nitrogen transformations in the decomposition of sugar cane trash, with special bearing upon Puerto Rico soil problems. Journ. Dept. Agric. Puerto Rico 15(2) : 113-146, 1931.

7. _ Preliminary microbiological studies in certain soils of the San Juan area, Puerto Rico. Int. Soc. of Sugar Cane Technologists. Fourth Congress. Bul. 58, 6 p., 1932.

8. Burgess, P. S. Can we predict probable fertility from soil biological data? Soil Se. 6(6):449-462, 1918.

9. Chardón, Carlos E. Estudio preliminar sobre la amonificación y nitrificación de los terrenos de Puerto Rico. (Preliminary studies on ammonification and nitrification of the soils of Puerto Rico.) Rev. Agric. Puerto Rico. 6(1):37-46, 1921.

10 a. Fraps, G. S., \& Sterges, A. J. Canses of low nitrification eapacity of certain soils. Soil Sc. 34(5) : 353-363, 1932.

$10 \mathrm{~b}$. Effect of sunlight on the nitrification of ammonium salts in soils. Soil Se. $39(2): 85-94,1935$.

11. Gerretsen, F. C. (Nitrification and denitrification in tropical soils.) Arch Suikerind 29:1397-530, 1921.

12. Gopala Rao, G. Newer aspects of nitrification I. Soil Sc. 38 (2) : $143,159,1934$.

13. Gopala Rao, G., \& Dhar, N. R. Photosensitized oxidation of ammonia and ammonium salts and the problem of nitrification in soils. Soil.Sc. 31(5) : 379-384, 1931. 
14. Hall, T. D. Nitrification in some South African soils. Soil Se. $12(4)$ : 301-363, 1921.

15. Nitrification in some South African soils. Part II. Soil Se. 18(3) : 219-235, 1924.

16. Harper, H. J. The determination of ammonia in soils. Soil Se. $18(5): 409-418,1924$.

17. Hutchinson, C. IV. Report of the Imperial Agr. Bacteriologist. Sci. Rpt. Agr. Res. Inst. Pusa 1918-19: 106-14, 1919.

18. Itano, Arao, \& Arakawa, Satiyo. Studies on the soils in rice fields. IV. Relation of ammonification, nitrification and denitrification of the soils to the crop yield of rice. Ber. Ohara Inst. Landw. Forsch. (Japan) 5(1):151-161, 1931.

19. Joshi, N. V. Rate of nitrification of different green manures and parts of green manures and the influence of crop residues on nitrification. Agric. Journ. India Sci. Congress, No. 1919: 395-413, 1919.

20. Kelley, W. P. Ammonification and nitrification in Hawaiian soils. Hawaii Agr. Expt. Sta. Bul. 37, 52 p., 1915.

21. Martin, F. S. \& IIassey, R. ㅍ. Nitrification in Sudan soils. Wellcome Trop. Res. Lat., Chem. Sect. Publ. 29, 29 p., 1923.

22. Pañganiban, $\mathbb{E}$. H. A study of nitrification in Philippine soils. Philippine Agr. and Forester 4: 81-91, 1915.

23. Peck, S. S. Influence of molasses on nitrification in cane soils. Hawaii Sugar Planters Assoc. Expt. Sta. Chem. Ser. Bul. $39: 1-23,1912$.

24. - Some biochemical investigations of Hawaiian soils, with special reference to fertilizing with molasses. Hawaii Sugar Planters Assoc. Expt. Sta. Agr. Chem. Ser. Bul. 34:1-39, 1910.

25. Plymen, F. J. \& Bal, D. V. The relative nitrifiability of different nitrogenous organic manures in some typical soils of the central provinces and Berar. Agr. Journ. India. 17: 551-9, 1922.

26. Prescott, J. A. Nitrification in Egyptian solis. Journ. Agr. Sci. 9(3) : 216-236, 1919.

27. Ramírez, J. H. Nitrificación de las tierras coloradas arcillosas ácidas de Puerto Rico. (Nitrificaction of the acid red clay soils of Puerto Rico). El Mundo Azucarero 10(9) : 263-267, 1923.

28. Roche, Raoul. Study of the nitrification of Egyptian soil. Nag-Hamadi, Bul. de I'Institut Egyptien 5(1) : 107-10, 1908.

29. Tiedjens, V. A. \& Robbins, W. R. The use of ammonia and nitrate nitrogen by eertain crop plants. New Jersey Agric. Expt. Sta. Bul. 526, 46 p., 1931.

30. Tiedjens, V. A. Factors affecting assimilation of ammonium and nitrate nitrogen, particularly in tomato and apple. Plant Physiology : 9(1) : 31-57, 1934.

31. Walksman, S. A. Microbiological analysis of soil as an index of soil fertility, V. Methods for the study of nitrification. Soil. Sc. 15(4) : 241-260, 1923. 
32. Waksman, S. A. Microbiological analysis of soil as an index of soil fertility; VI. Nitrification. Soil Sc. 16(1):55-67, 1923.

33. Principles of soil microbiology. p. 695-699. London, Balliere, Tindall \& Cox. 2d ed. 1931.

34. Walton, J. $\boldsymbol{H}$. Nitrification of calcium cyanamide in some Indian soils. Mem. Dept. Agr. India, Bacteriol. Ser. 2: 35-64, 1928.

35. The influence of alkali salts on nitrification in some Indian soils. Indian Journ. Agric. Sci. 1(4):480-494, 1931.

36. Watt, R. D. Nitrification in Transvaal soils. Transvaal Dept. Agr. Ann. Rept. 1908: 274-277, 1909.

37. Wilcox, O. W. The work of Arrhenius on Java cane soils. A summary of the investigations made for the Java Sugar Syndicate. Comparison with the Cuban Cane Soil Survey. Facts About Sugar 23(36) : 854-859, 1928. 